\title{
Article \\ Thermal Stability of the Copper and the AZO Layer on Textured Silicon
}

\author{
Ping-Hang Chen, Wen-Jauh Chen * and Jiun-Yi Tseng \\ Graduate School of Materials Science, National Yunlin University of Science and Technology, \\ 123 University Road, Section 3, Douliou 64002, Taiwan; M108470121@yuntech.edu.tw (P.-H.C.); \\ jytseng@yuntech.edu.tw (J.-Y.T.) \\ * Correspondence: chenwjau@yuntech.edu.tw; Tel.: +886-5-534-2601-3069
}

Citation: Chen, P.-H.; Chen, W.-J.; Tseng, J.-Y. Thermal Stability of the Copper and the AZO Layer on Textured Silicon. Coatings 2021, 11, 1546. https://doi.org/10.3390/ coatings11121546

Academic Editor: Rafal Chodun

Received: 20 November 2021 Accepted: 14 December 2021 Published: 16 December 2021

Publisher's Note: MDPI stays neutral with regard to jurisdictional claims in published maps and institutional affiliations.

Copyright: (c) 2021 by the authors. Licensee MDPI, Basel, Switzerland. This article is an open access article distributed under the terms and conditions of the Creative Commons Attribution (CC BY) license (https:// creativecommons.org/licenses/by/ $4.0 /)$.

\begin{abstract}
Transparent conductive oxide (TCO) film is the most widely used front electrode in silicon heterojunction (SHJ) solar cells. A copper metallization scheme can be applied to the SHJ process. The abundance of zinc in the earth's crust makes aluminum-doped zinc oxide (AZO) an attractive low-cost substitute for indium-based TCOs. No work has focused on the properties of the copper and AZO layers on the textured silicon for solar cells. This work deposited an aluminum-doped zinc oxide layer and copper metal layer on textured (001) silicon by a sputtering to form $\mathrm{Cu} / \mathrm{AZO} / \mathrm{Si}$ stacks. The structures of $\mathrm{Cu} / \mathrm{AZO} / \mathrm{Si}$ are characterized by scanning electron microscope (SEM), scanning transmission electron microscope (STEM), and energy-dispersive X-ray spectrometer (EDS). The results show that the copper thin film detached from AZO in the valley of the textured silicon substrate at a temperature of $400{ }^{\circ} \mathrm{C}$. Additionally, the gap between the copper and AZO layers increases as temperature increases, and the $65 \mathrm{~nm}$ thickness AZO layer was found to be preserved up to $800{ }^{\circ} \mathrm{C}$.
\end{abstract}

Keywords: textured silicon; aluminum-doped zinc oxide; solar cells; diffusion barrier; thermal stability

\section{Introduction}

In silicon heterojunction (SHJ) solar cells, the hydrogenated amorphous silicon (a-Si:H) thin layer is too low in transverse conductivity to collect charge carriers horizontally over the metal electrodes effectively. Additional transparent conductive oxide layers such as Sn-doped $\mathrm{In}_{2} \mathrm{O}_{3}$ (ITO) are deposited at the top. In addition to charge collection, another essential function of the front-end transparent conductive oxide (TCO) layer is to act as an anti-reflective layer. Because ITO has excellent performance with low resistivity and high transparency, ITO is currently the most widely used transparent conductive oxide [1]. However, $\operatorname{In}_{2} \mathrm{O}_{3}$ has the disadvantage of high refining and production costs and the relative scarcity of indium ore. Sn is also susceptible to price fluctuations (compared to other elements (e.g., $\mathrm{Zn}$ ). Finding a replacement for ITO could reduce the costs of the production of $\mathrm{SHJ}$ solar cells. Aluminum-doped zinc oxide (AZO) is based on zinc oxide. Zinc oxide $(\mathrm{ZnO})$ is a potential candidate in $\mathrm{TCO}$, known as $\mathrm{ZnO}$, a natural type of semiconductor with an energy gap of $3.4 \mathrm{eV}$ (intrinsic n-type semiconductor) [2]. Compared with ITO, AZO has high thermal stability and a low price, and is mineral-rich, relatively non-toxic, and has an increased transparency of the visible light range, as well as other advantages [3-6].

As mentioned above, reducing costs and improving conversion efficiency have always been the solar cell industry's theme. With the continuous progress of solar cell industry technology and policy promotion, the public's attention gradually shifted to the cost of electricity, and high-efficiency batteries have attracted attention. The three high costs of SHJ cells are for the silicon chip, conductive silver paste, and target material. Because of these three high-cost components, various cost reductions will help improve SHJ cells' 
competitiveness, including reducing the consumption of raw materials and introducing new technologies.

In $\mathrm{SHJ}$ technology, the low-temperature silver paste is used. Still, the conductivity of low-temperature silver paste is significantly lower than that of bulk silver, so the conductivity of silver electrodes in SHJ solar cells is lower than that of silver electrodes in c-Si solar cells. Therefore, the use of silver paste in a typical 3-5 bus configuration limits efficiency and increases the cost of SHJ solar cells, estimated to cost $30 \%$ due to the use of a large number of expensive low-temperature net-printed silver paste processes. The electroplating technology can effectively reduce the cost of electrodes. The $\mathrm{Cu}$ metallization process introduces to SHJ solar cells, and it is crucial to improve the SHJ solar cell industry's competitiveness. At present, there are some reports on the application of copper plating technology to SHJ solar cells [7-10].

$\mathrm{Li}$ et al. used a rotating coating method to coat the resin (photo-resistance) on the n-type $156 \mathrm{~mm}$ SHJ surface [10]. Then pattern the resin by the inkjet printer (Dimatix DMP 2800). Copper is then plated to the $\mathrm{p}$-i type a-Si: H's ITO surface using field-induced power generation plating (FIP). The efficiency of the $\mathrm{SHJ}$ solar cells produced by $\mathrm{Li}$ is $18.8 \%$ (Voc $\mathrm{s}$ $717 \mathrm{mV}$, Jsc s $35.4 \mathrm{~mA} / \mathrm{cm}^{2}$, and F.F. s 74\%). Dabirian et al. introduced the double-mask layer strategy for the metallization of SHJ solar cells. They combined the nanosecond laser patterning and Ni-Cu electroplating. The results showed that the Ni-Cu metallization qualities of their process are comparable to Ag screen-printing and lithography-based $\mathrm{Cu}$ plating [11]. Meza et al. compared ZnO:Al films instead of the usual ITO as the front TCO in rear emitter SHJ solar cells. An indium-free mono facial cell achieved $\eta=22.5 \%$ showing that the replacement of ITO/Ag by $\mathrm{ZnO}: \mathrm{Al} / \mathrm{Ag}$ as a back contact produces cells with practically the same efficiency [12].

In SHJ technology, the metallic contacts are generally deposited on a transparent conductive oxide (TCO). Contact metallization on TCOs is typically performed by screenprinting of low-temperature Ag pastes. Electroplating of copper is becoming more attractive to reduce precious Ag consumption. However, copper has a high diffusion coefficient and high solubility in silicon and formation copper silicide at low temperature. TCO can also serve as a barrier to $\mathrm{Cu}$ migration. Additionally, the $\mathrm{Cu}$ directly electroplated on TCO is usually tricky. Kang et al. also reported the electroplated copper films fail to adhere to Si during rapid heating and cooling [13]. Thus, an additional seed layer is usually used. The plating process sequence involves seed layers usually deposited by physical vapor deposition (PVD). Additionally, copper electroplating by the D.C. power supplier is the most commonly adopted method.

Li et al. and Dabirian et al. confirmed that the plated copper process could be applied to SHJ solar cells. However, their reports focused on the electroplating $\mathrm{Ni}-\mathrm{Cu}$ (or $\mathrm{Cu}$ ) on ITO $[10,11]$. Meza et al. showed that the ITO/Ag could be replaced by ZnO:Al/Ag [12]. There have been no reports about the electroplating $\mathrm{Cu}$ on $\mathrm{AZO}$ till now. Additionally, about the role of seed copper layer on AZO. In this work, we studied the thermal stability of the copper seed layer and the AZO layer on the textured silicon.

\section{Materials and Methods}

As substrate, commercially available single crystal phosphorus-doped $\left(\begin{array}{lll}0 & 0 & 1\end{array}\right)$ oriented silicon wafers with textured roughness around 3-5 $\mu \mathrm{m}$ were used. The acetone and $\mathrm{H}_{2} \mathrm{SO}_{4} / \mathrm{H}_{2} \mathrm{O}_{2}$ solution were applied to clean the textured silicon substrate. To remove the native oxide of the silicon, the substrate dip into hydrogen fluoride solution before loading into the vacuum chamber. The AZO and copper films were sputter-deposited onto textured silicon substrates in a direct current/radio-frequency (dc/rf) magnetron sputtering system. The AZO films were sputtered from an AZO target with an rf power supply in an Ar ambient of $99.999 \%$ purity. The base pressure of the vacuum chamber was $2 \times 10^{-7}$ Torr. The rf power was held at $60 \mathrm{~W}$ during deposition. Additionally, a fixed Ar flow rate and the operation pressure were $50 \mathrm{sccm}$ and $6 \times 10^{-3}$ Torr, respectively. A fixed Ar flow rate of $25 \mathrm{sccm}$ and the dc power held at $30 \mathrm{~W}$ during the copper film deposition. 
The AZO and copper films were deposited onto a textured silicon substrate at $25{ }^{\circ} \mathrm{C}$ during the sputtering process. The sputtered AZO and copper films' thicknesses were $65 \mathrm{~nm}$ and $220 \mathrm{~nm}$, respectively. AZO films and copper films were subsequently sputter-deposited without breaking the vacuum. The samples are designed for $\mathrm{Cu} / \mathrm{AZO} / \mathrm{Si}$.

To evaluate the copper seed layer and the barrier property of the AZO layer, an annealing temperature from 300 to $800{ }^{\circ} \mathrm{C}$ was selected. The as-deposited samples were annealed in the furnace at $300-800{ }^{\circ} \mathrm{C}$ for $10 \mathrm{~min}$ in an $\mathrm{Ar} / \mathrm{H}_{2}$ atmosphere. The structure was obtained using a scanning electron microscope (SEM, JEOL Ltd., Tokyo, Japan) and a scanning transmission electron microscope (STEM, JEOL Ltd. L, Tokyo, Japan). SEM and STEM were performed on JSM-6360 and a JEM-ARM200, respectively. A STEM that was equipped with an energy dispersive X-ray spectrometer (EDS, Oxford Instruments, Abingdon, UK) was used to determine the chemical composition and STEM-EDS compositional maps of all samples. A focus ion beam (FIB) resembled a scanning electron microscope (SEM) operating at $20 \mathrm{kV}$ and was used for a cross-sectional view of SEM examination. The sample's surface is protected with an about $2 \mu \mathrm{m}$ Pt layer formed by an electron beam within the FIB chamber. The sample was then ion-milled using a focused beam of gallium ions to give a cross-section view. The tape and peel-off tests were conducted on the as-deposited sample. For the tape and peel-off tests, about $15 \mu \mathrm{m}$ thick copper layer was deposited on the $\mathrm{Cu} / \mathrm{AZO} / \mathrm{Si}$ by electroplating. Tape tests were conducted by peeling the $3 \mathrm{M}$ Scotch tape off at $180^{\circ}$. The peel-off tests were conducted at an angle of $180^{\circ}$ with a constant speed of $30 \mathrm{~mm} / \mathrm{min}$.

\section{Results and Discussion}

SEM images for the $\mathrm{Cu} / \mathrm{AZO} / \mathrm{Si}$ samples annealed at $300,500,600$, and $800{ }^{\circ} \mathrm{C}$ are presented in Figure 1. The pyramid shapes with uniform $\mathrm{Cu}$ and $\mathrm{AZO}$ thin layers exist on the surface of the samples after annealing at $300^{\circ} \mathrm{C}$ (Figure 1a). The surface is smooth for the annealing of the samples at temperatures $300^{\circ} \mathrm{C}$. The surface of the as-deposited sample is the same as the sample annealing at $30{ }^{\circ} \mathrm{C}$ for $10 \mathrm{~min}$. The surface became rough when the annealing temperature was higher than $500^{\circ} \mathrm{C}$, as shown in Figure $1 \mathrm{~b}-\mathrm{d}$.
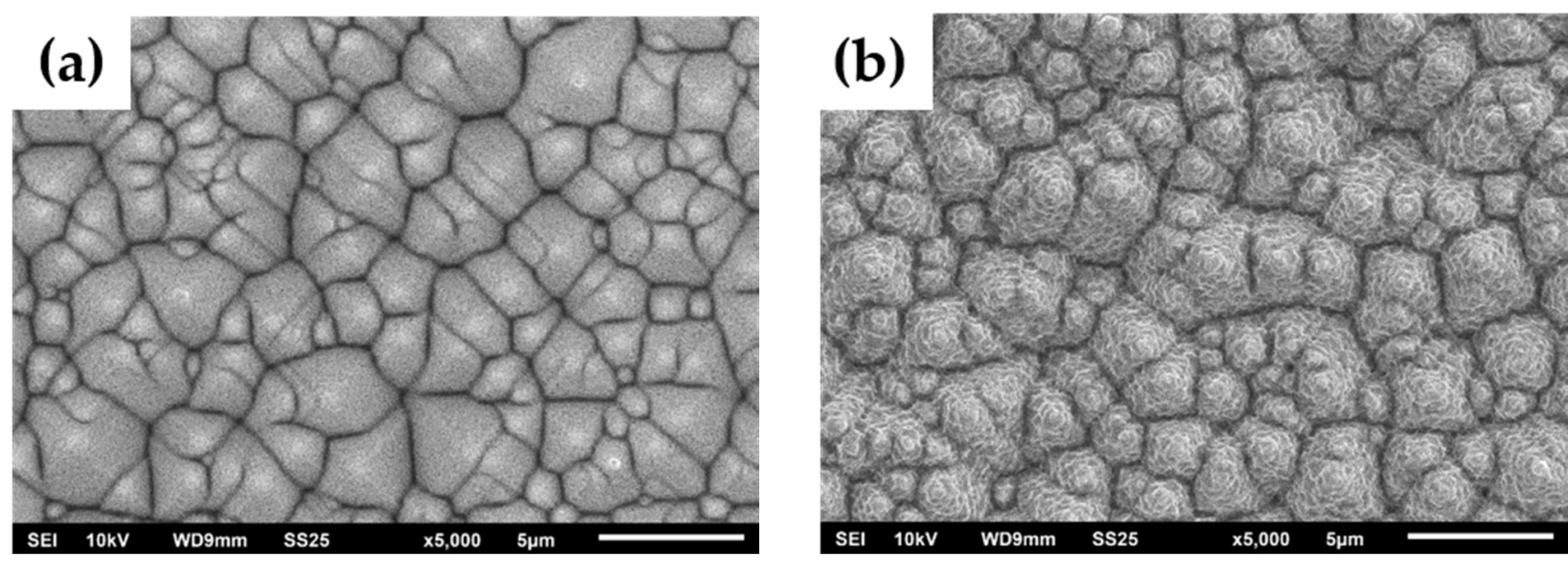

Figure 1. Cont. 

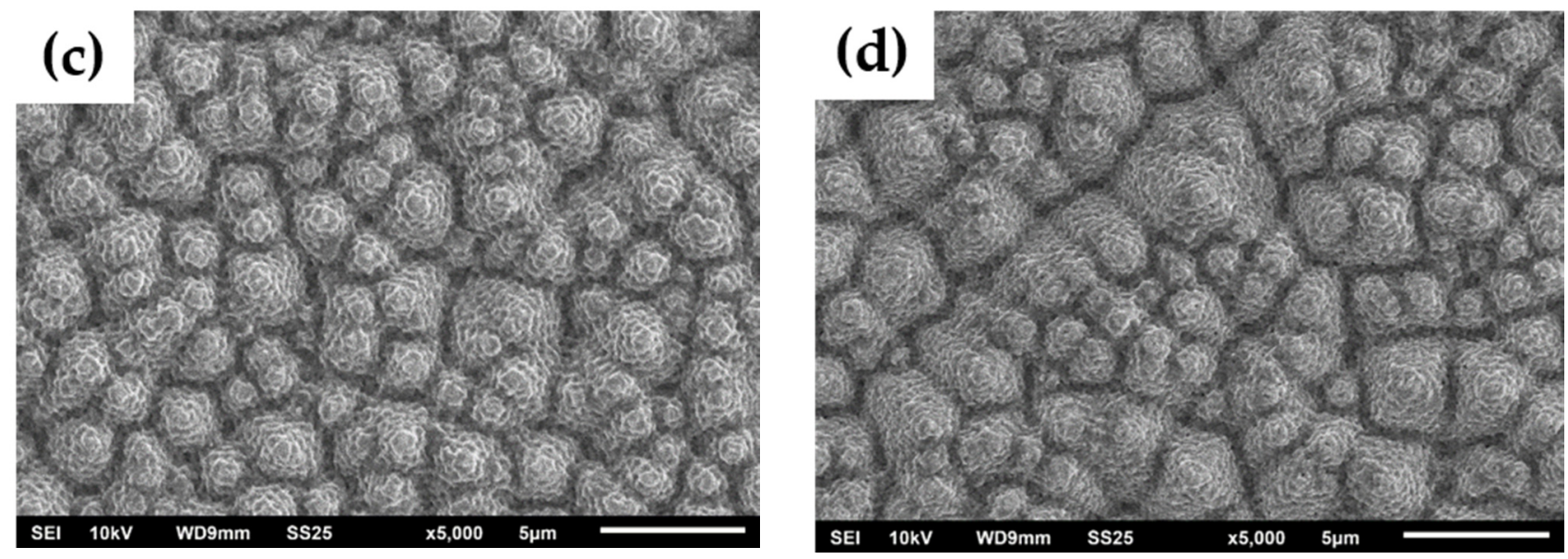

Figure 1. SEM images for the $\mathrm{Cu} / \mathrm{AZO} / \mathrm{Si}$ samples annealed at (a) 300, (b) 500, (c) 600, and (d) $800{ }^{\circ} \mathrm{C}$.

The cross-sectional views of SEM for the Cu/AZO/Si samples annealed at 400, 600, and $800{ }^{\circ} \mathrm{C}$ are shown in Figure 2. The copper thin films were continuous for all samples. However, the thin films $(\mathrm{Cu} / \mathrm{AZO}$ or $\mathrm{Cu}$ ) were detached from the substrate (silicon or $\mathrm{AZO} / \mathrm{Si}$ substrate) in some areas for the samples after $400^{\circ} \mathrm{C}$ annealing. It was hard to know the composition of the detached thin film $(\mathrm{Cu} / \mathrm{AZO}$ or $\mathrm{Cu})$ from FIB-SEM. Additionally, the separation of thin films and silicon substrate (or AZO/Si) became severe at temperatures of 600 and $800{ }^{\circ} \mathrm{C}$. It was also hard to confirm the gap formed at the $\mathrm{Cu}$ and $\mathrm{AZO} / \mathrm{Si}$ or $\mathrm{Cu} / \mathrm{AZO}$ and silicon interfaces.
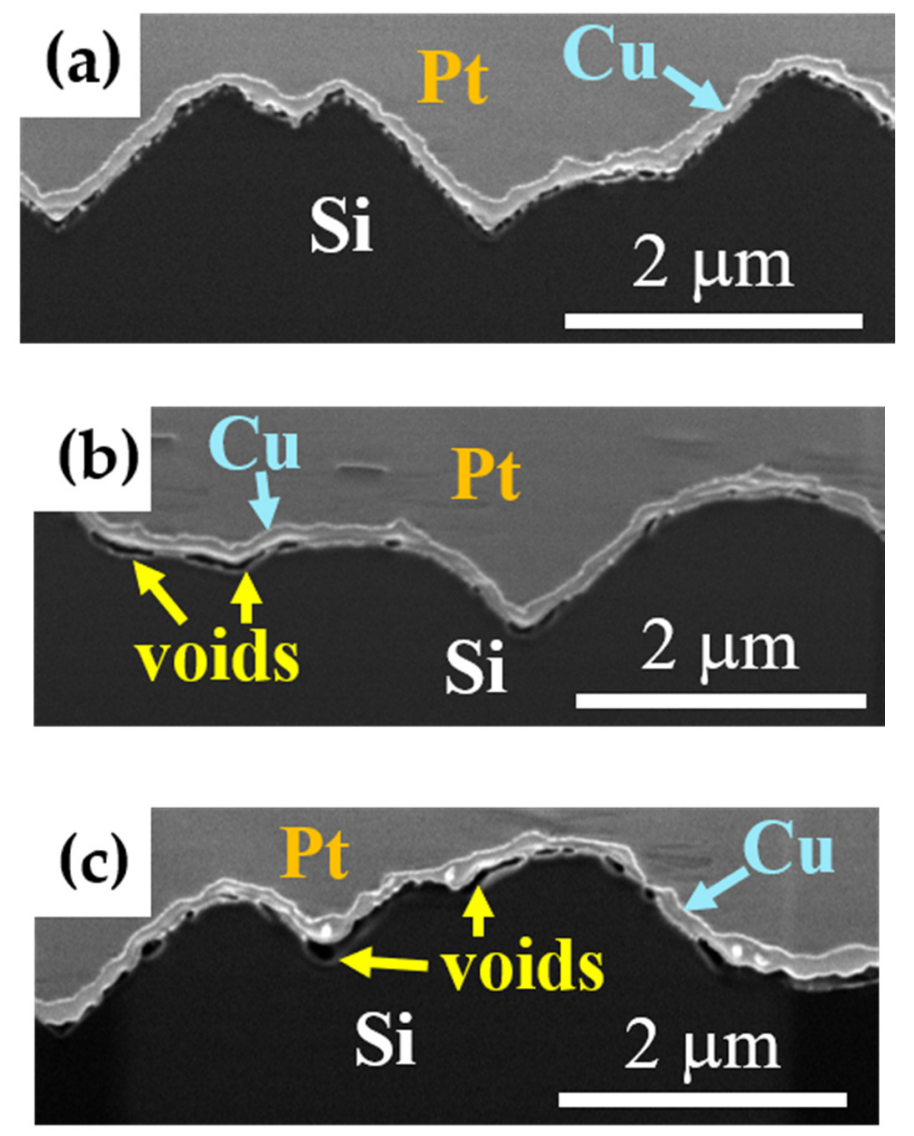

Figure 2. The cross-sectional views of SEM for the Cu/AZO/Si samples were annealed at (a) 400, (b) 600 , and (c) $800^{\circ} \mathrm{C}$. 
The low and high magnification TEM micrographs of $\mathrm{Cu} / \mathrm{AZO} / \mathrm{Si}$ sample annealed at $300{ }^{\circ} \mathrm{C}$ are shown in Figure $3 \mathrm{a}, \mathrm{b}$, respectively. The multilayer is preserved after annealing at $300{ }^{\circ} \mathrm{C}$ for $10 \mathrm{~min}$. The structure of the as-deposited sample is the same as the sample annealing at $300{ }^{\circ} \mathrm{C}$ for $10 \mathrm{~min}$. Figure $3 \mathrm{c}-\mathrm{f}$ shows the EDS maps of $\mathrm{Si}, \mathrm{Cu}, \mathrm{Zn}$, and $\mathrm{O}$, respectively. The $\mathrm{Zn}$ and $\mathrm{O}$ elements are overlapped and located between the copper and silicon elements. The elemental maps reveal that the $\mathrm{Cu} / \mathrm{AZO} / \mathrm{Si}$ stack structure is very stable after annealing at $300{ }^{\circ} \mathrm{C}$ for $10 \mathrm{~min}$. The line scan across the $\mathrm{Cu} / \mathrm{AZO} / \mathrm{Si}$ using STEM-EDS is shown in Figure $4 \mathrm{a}$. Figure $4 \mathrm{~b}$ shows the intensity signal of the Si, $\mathrm{Zn}, \mathrm{O}, \mathrm{Al}$, and $\mathrm{Cu}$ elements along the yellow line, shown in Figure 4a. The signal of the aluminum element is almost at the noise level due to the small aluminum amount in the AZO layer. The spot analysis of the AZO layer is shown in Figure 4c. The amount of aluminum is only about 1.3 at.\%. The distribution of zinc and oxygen in the $\mathrm{Cu} / \mathrm{AZO} / \mathrm{Si}$ stack is located at a scale between 180 and $245 \mathrm{~nm}$, which reveals that the thickness of the AZO layer is near $65 \mathrm{~nm}$. There were interfacial layers at the scale of 165-190 nm and 235-260 nm (Figure 4b). The width of the interface layer was caused by the situation where the interface plane was not perpendicular to the figure shown in Figure $4 \mathrm{a}$. The thickness of the AZO thin film is also near $65 \mathrm{~nm}$, from Figure 3b-f. The thickness of the copper thin film is about $220 \mathrm{~nm}$, as shown in Figure 3b,d. Only a silicon signal emerges at a scale below $160 \mathrm{~nm}$. Additionally, the copper signal was presented at a scale almost greater than $260 \mathrm{~nm}$. The line scan shows that $\mathrm{Cu} / \mathrm{AZO} / \mathrm{Si}$ structure is maintained after annealing at $300{ }^{\circ} \mathrm{C}$. The result of the line scan (Figure 4) agrees with the work of the TEM and EDS map (Figure 3).

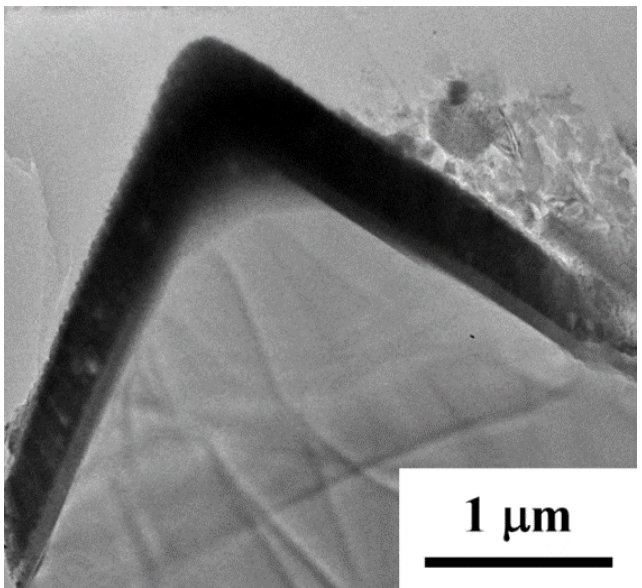

(a)

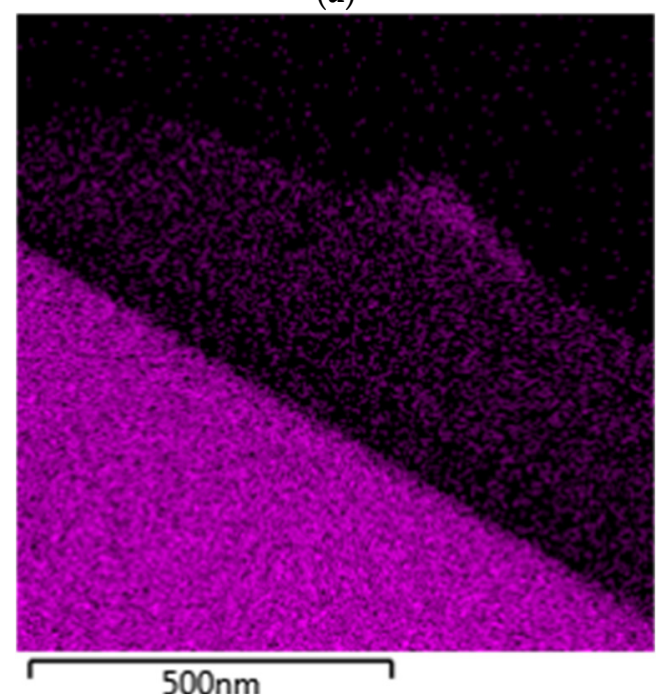

(c)

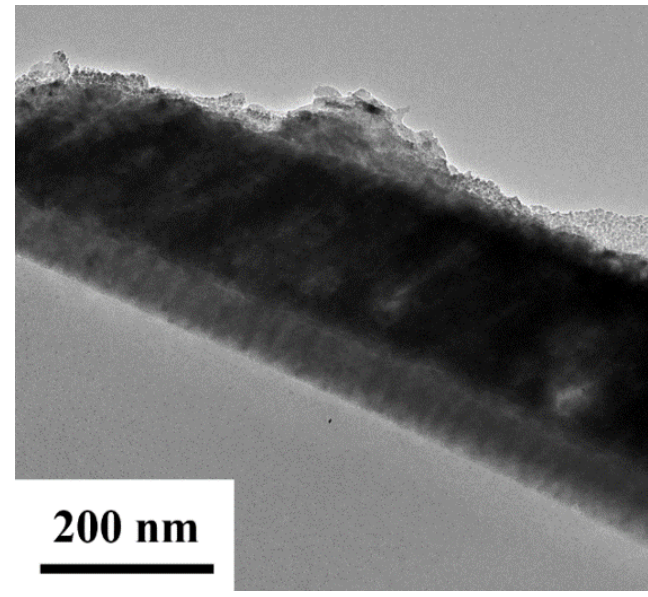

(b)

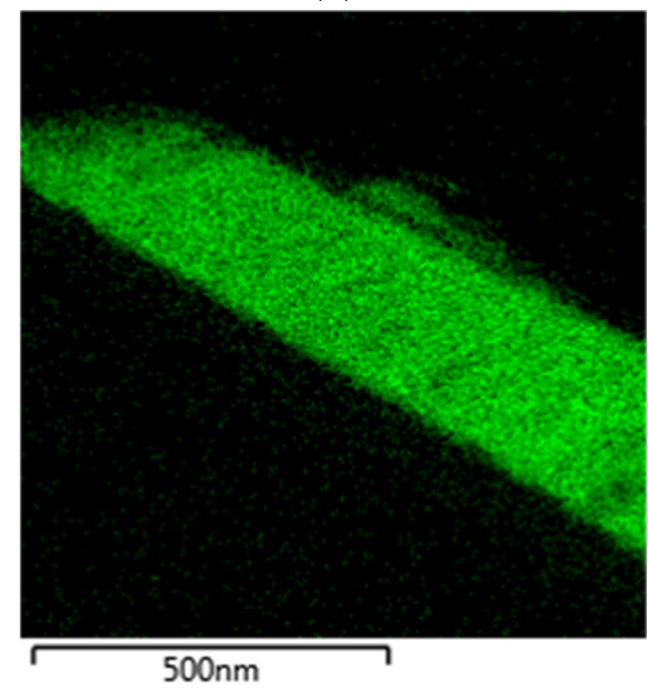

(d)

Figure 3. Cont. 


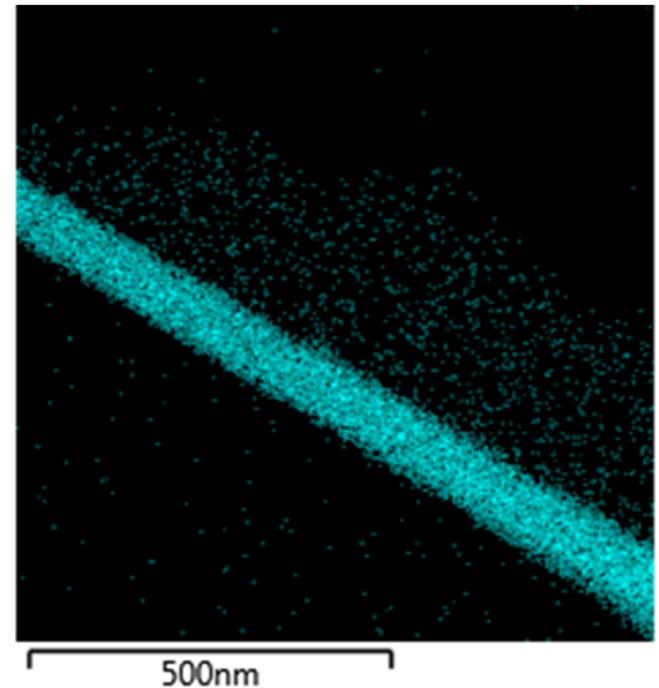

(e)

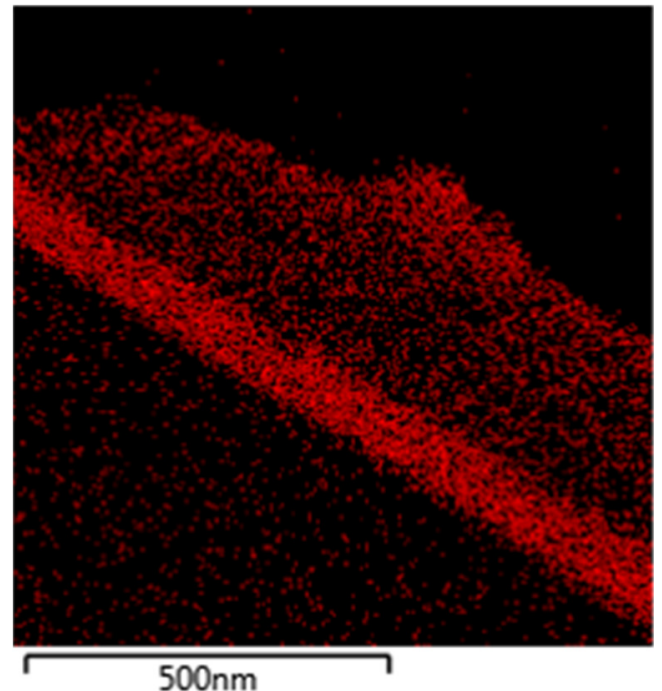

(f)

Figure 3. (a) Low and (b) high magnification TEM micrographs of $\mathrm{Cu} / \mathrm{AZO} / \mathrm{Si}$ sample annealed at $300{ }^{\circ} \mathrm{C}$, respectively. EDS map of (c) $\mathrm{Si},(\mathbf{d}) \mathrm{Cu},(\mathbf{e}) \mathrm{Zn}$, and (f) O elements.

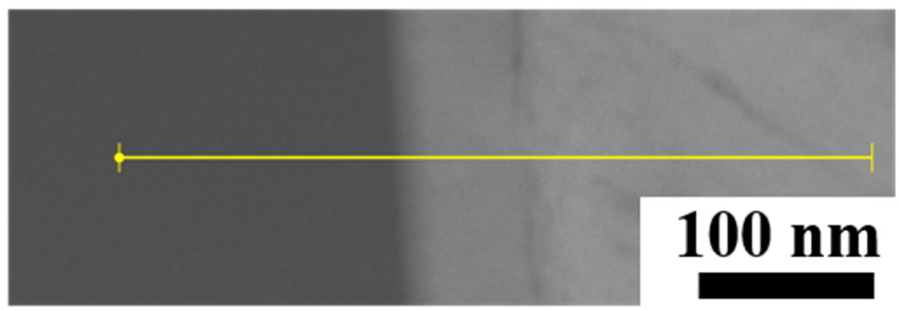

(a)

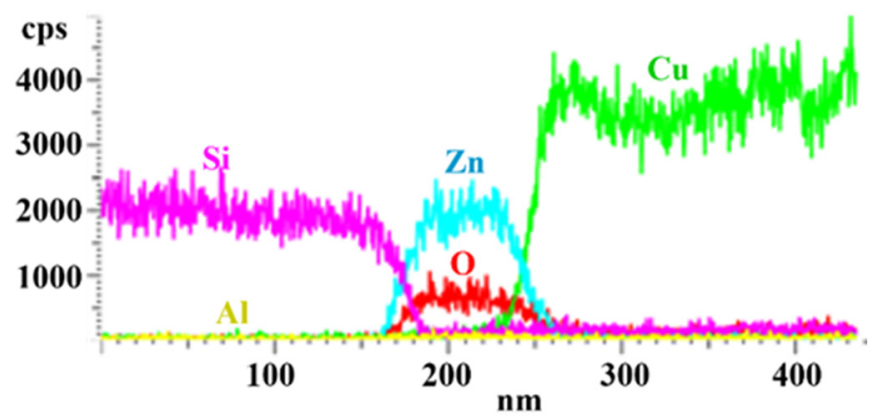

(b)

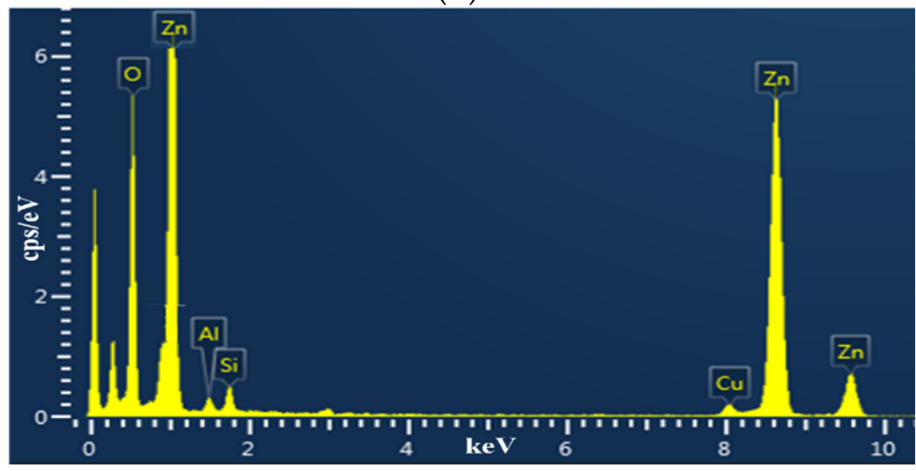

(c)

Figure 4. STEM-EDS line scan across the $\mathrm{Cu} / \mathrm{AZO} / \mathrm{Si}$ sample annealed at $300^{\circ} \mathrm{C}$. (a) STEM image and (b) intensity signal of $\mathrm{Si}, \mathrm{Zn}, \mathrm{O}, \mathrm{Al}$, and $\mathrm{Cu}$ elements along the yellow line. (c) EDS spectra of AZO layer. 
For the annealing of the samples at temperatures of 500,600 , and $700{ }^{\circ} \mathrm{C}$, STEM images also confirm that the copper thin film detached from $\mathrm{AZO} / \mathrm{Si}$ in the valley of the textured silicon substrate after annealing. Additionally, the gap between the copper and AZO layers increases as temperature increases. For the sample annealed at $800{ }^{\circ} \mathrm{C}$, the TEM and STEM micrographs of $\mathrm{Cu} / \mathrm{AZO} / \mathrm{Si}$ are presented in Figure $5 \mathrm{a}, \mathrm{b}$, respectively. Additionally, the EDS map of $\mathrm{Si}, \mathrm{Cu}, \mathrm{Zn}$, and $\mathrm{O}$ is illustrated in Figure $5 \mathrm{c}-\mathrm{f}$, respectively. The copper layer starts to agglomerate and almost leaves the textured structure's valley area from Figure 5. The AZO layer seems stable even after annealing at $800^{\circ} \mathrm{C}$, and the copper element stays above the AZO layer. The copper layer also presents the oxygen signal from Figures $3 f$ and $5 \mathrm{f}$. The origin of oxygen migration to the copper layer needs further identification. The STEM-EDS evidence that copper does not diffuse through the AZO layer to the silicon substrate. Therefore, the AZO thin film is also an excellent diffusion barrier layer to prevent copper diffuse into the silicon substrate.

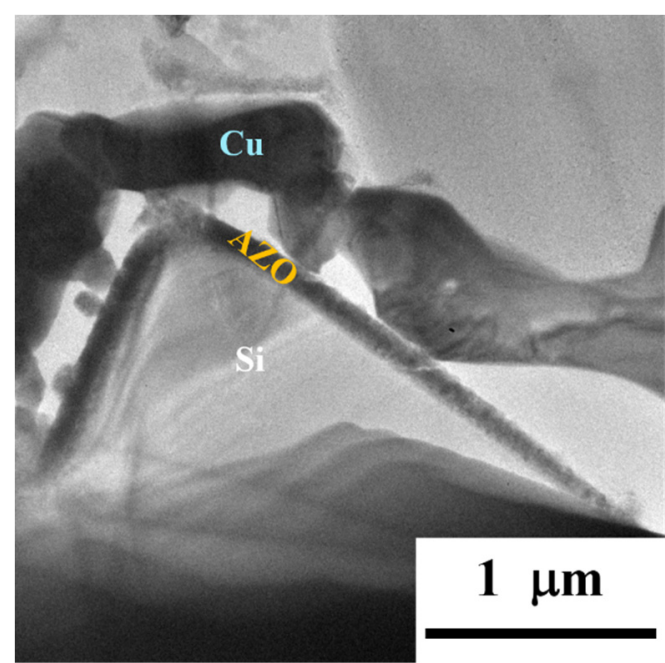

(a)

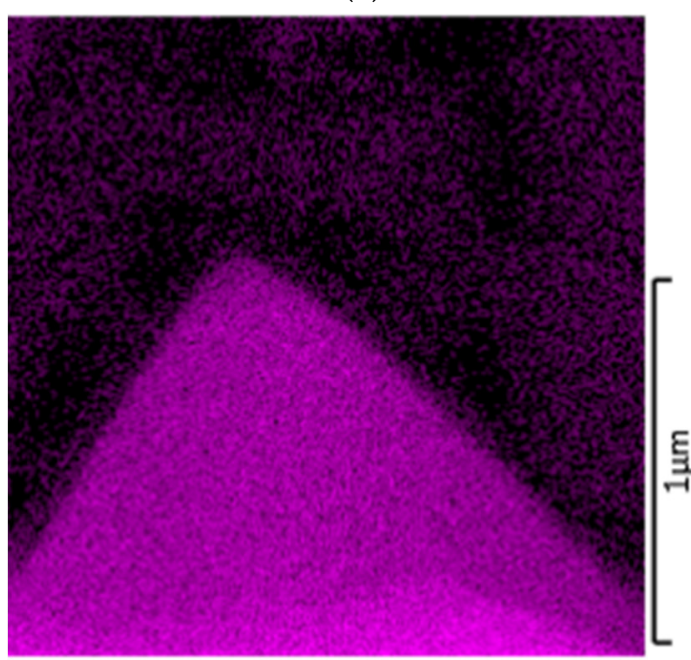

(c)

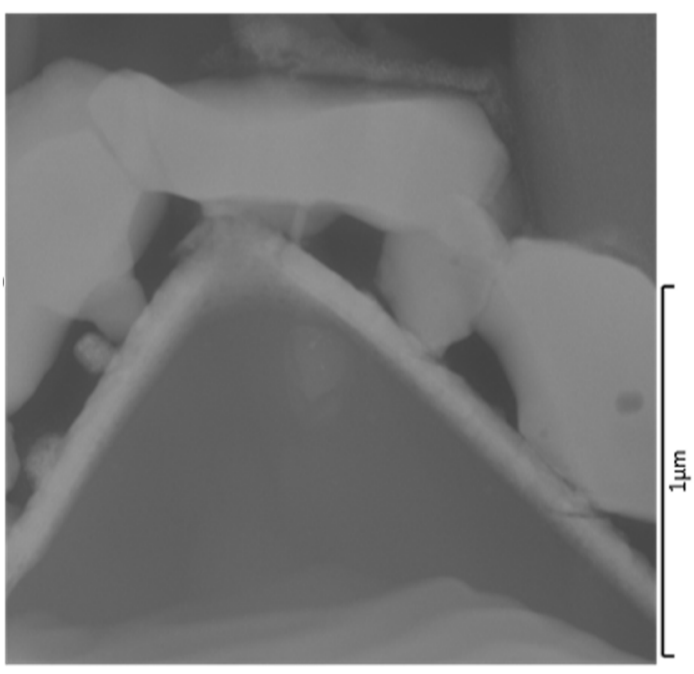

(b)

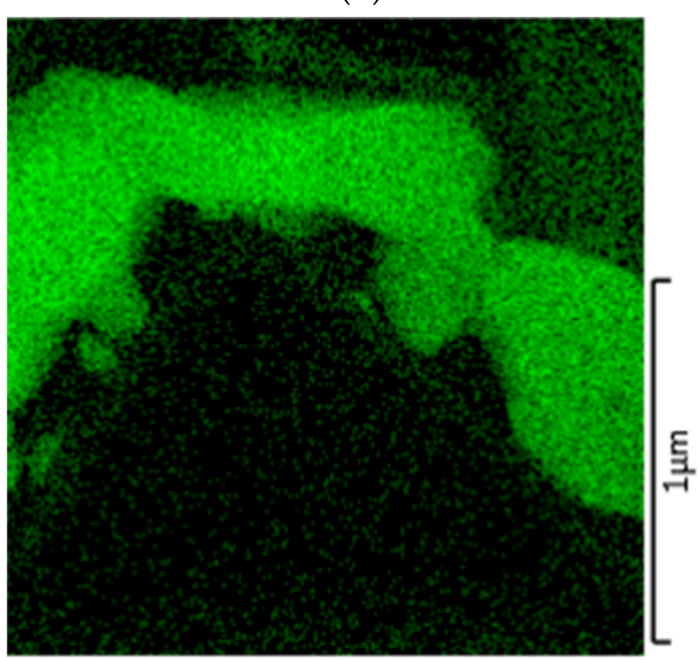

(d)

Figure 5. Cont. 


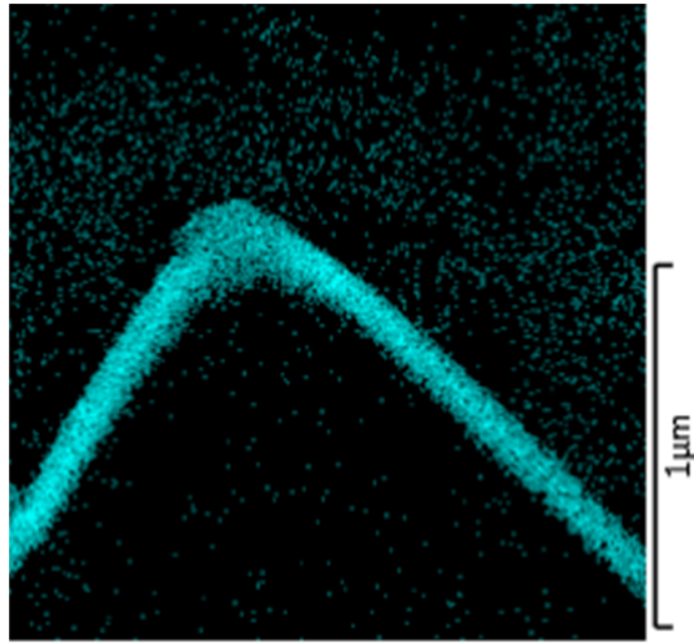

(e)

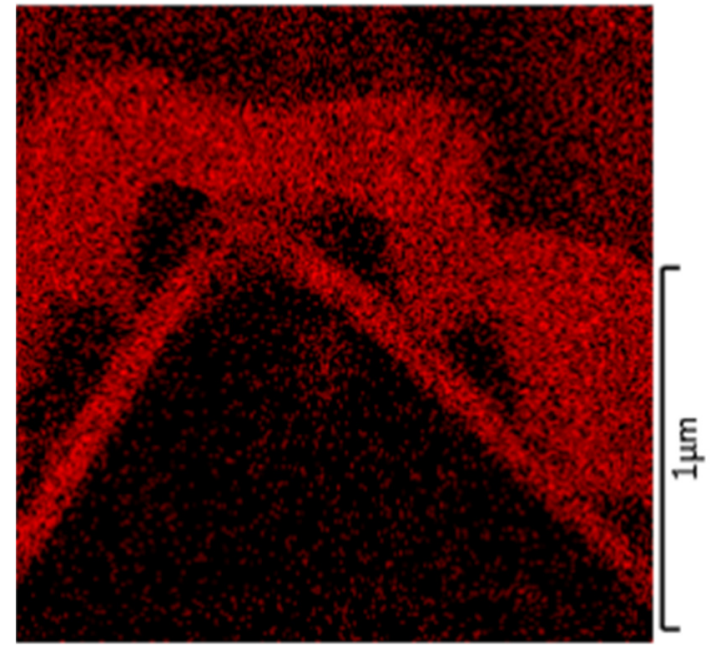

(f)

Figure 5. (a) TEM micrograph and (b) STEM micrograph for the sample annealed at $800^{\circ} \mathrm{C}$ for 10 min. Additionally, EDS maps of (c) Si, (d) Cu, (e) Zn, and (f) O elements.

To understand the formation of the gap at the copper and AZO/Si interface, the tape and peel-off tests were used to evaluate copper's adhesion on the AZO/Si substrate. About $15 \mu \mathrm{m}$ thick copper layer deposited on the as-deposited $\mathrm{Cu} / \mathrm{AZO} / \mathrm{Si}$ by electroplating for tape and peel-off tests. The sample is designed as E-Cu/Cu/AZO/Si. No copper remained on the $\mathrm{AZO} / \mathrm{Si}$ after the $180^{\circ}$ tape test. Figure 6 shows the peel force diagram for the $\mathrm{E}-\mathrm{Cu} / \mathrm{Cu} / \mathrm{AZO} / \mathrm{Si}$ sample. The maximum and average peel force values were 0.39 and $0.2 \mathrm{~N} / \mathrm{mm}$, respectively. The results indicated that the adhesion between copper and $\mathrm{AZO} / \mathrm{Si}$ is weak. It can imply that the adhesion strength will decrease as annealed temperature increases due to the voids emerging when the temperature is higher than $400{ }^{\circ} \mathrm{C}$. Lee also reported a copper seed layer deposited on an indium tin oxide (ITO) by electron-beam evaporation [14]. After the copper seed layers were deposited, copper/silver $(\mathrm{Cu} / \mathrm{Ag})$ metal stacks were plated on the sample using the light-induced plating (LIP) technique. Additionally, adhesive contact between copper and ITO was evaluated by the tape test [14]. The results show that pure copper was mostly detached from the ITO surface after the tape test. Their results also indicated that the adhesive force between copper and ITO/Si is very weak. Kang deposited the $(\mathrm{Ti}(30 \mathrm{~nm}) / \mathrm{Cu}(100 \mathrm{~nm}))$ on p-type $\left(\begin{array}{lll}1 & 0 & 0\end{array}\right) \mathrm{Si}$ as a seed layer. Then thick copper was electroplated on the seed layer [13]. They found that rapid thermal annealing (RTA) caused the electroplated films to fail to adhere to the Si. The adhesion strength of copper and ITO or Si was deficient from Lee's and Kang's reports. Our result shows that the adhesion between copper and AZO/Si is very weak, from the tape test. Additionally, the gap formed at the copper and AZO/Si interface easily after high-temperature annealing. It can imply that the copper detached from the $\mathrm{AZO} /$ textured silicon after annealing due to the weak adhesion of copper thin films on the AZO/Si. Additionally, the separation of copper and AZO/Si became serious at high-temperature treatments. 


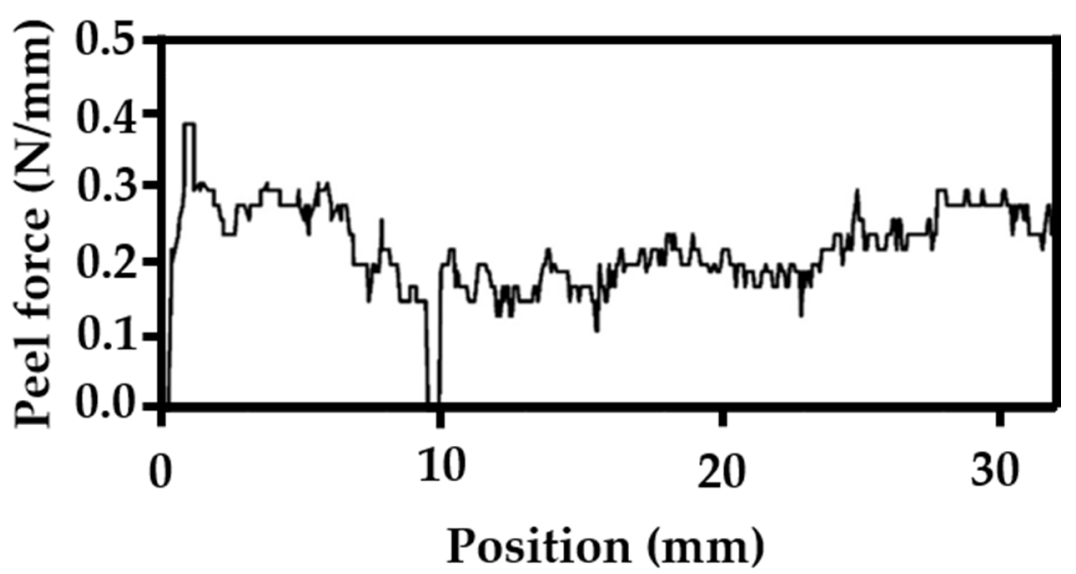

Figure 6. The peel-force measurement of $\mathrm{E}-\mathrm{Cu} / \mathrm{Cu} / \mathrm{AZO} / \mathrm{Si}$ sample.

\section{Conclusions}

This paper reports the thermal stability of the copper layer and the AZO layer on textured silicon. The $\mathrm{Cu} / \mathrm{AZO} / \mathrm{Si}$ stack seems preserved after annealing at temperatures of 300-800 ${ }^{\circ} \mathrm{C}$. Although the copper thin film detached from the AZO/Si substrate, the sputtering AZO layer with a thickness of $65 \mathrm{~nm}$ was a sound diffusion barrier against $\mathrm{Cu}$ up to $800^{\circ} \mathrm{C}$. The copper thin film detached from AZO in the valley of the textured silicon substrate at $400{ }^{\circ} \mathrm{C}$. Additionally, the gap between the copper and AZO layers increases as temperature increases. It can imply that the copper detachment from AZO occurs due to the weak adhesive strength of copper thin films on the AZO.

Author Contributions: Performing the experiments and data collection, P.-H.C.; conceptualization, funding acquisition, writing — original draft preparation, reviewing and editing, supervision, project administration, W.-J.C.; writing-review \& editing, supervision, J.-Y.T. All authors have read and agreed to the published version of the manuscript.

Funding: This research was funded by the Ministry of Science and Technology of Taiwan, grant number MOST 109-2221-E-224-034.

Institutional Review Board Statement: Not applicable.

Informed Consent Statement: Not applicable.

Data Availability Statement: Not applicable.

Acknowledgments: This research was funded by the Ministry of Science and Technology of Taiwan, grant number MOST 109-2221-E-224-034. The authors would like to thank Tseng's laboratory at the Graduate School of Materials Science, National Yunlin University of Science and Technology, for the support.

Conflicts of Interest: The authors declare no conflict of interest. The funders had no role in the study's design, in the collection, analyses, or interpretation of data, in the writing of the manuscript, or in the decision to publish the results.

\section{References}

1. Tohsophon, T.; Dabirian, A.; Wolf, S.D.; Morales-Masis, M.; Ballif, C. Environmental stability of high-mobility indium-oxide based transparent electrodes. APL Mater. 2015, 3, 116105. [CrossRef]

2. Sernelius, B.E.; Berggren, K.F.; Jin, Z.C.; Hamberg, I.; Granqvist, G. Band-gap tailing of ZnO by means of heavy Al doping. Phys. Rev. B 1988, 37, 10244-10248. [CrossRef] [PubMed]

3. Cruz, A.; Wang, E.C.; Morales-Vilches, A.B.; Meza, D.; Neubert, S.; Szyszka, B.; Schlatmann, R.; Stannowski, B. Effect of front TCO on the performance of rear-junction silicon heterojunction solar cells: Insights from simulations and experiments. Sol. Energy Mater. Sol. Cells 2019, 195, 339-345. [CrossRef]

4. Madani Ghahfarokhi, O.; Chakanga, K.; Geissendoerfer, S.; Sergeev, O.; Maydell, K.V.; Agert, C. DC-sputtered ZnO:Al as transparent conductive oxide for silicon heterojunction solar cells with $\mu \mathrm{c}-\mathrm{Si}$ :H emitter. Prog. Photovolt Res. Appl. 2015, 23, 1340. [CrossRef] 
5. Senaud, L.L.; Christmann, G.; Descoeudres, A.; Geissbuhler, J.; Barraud, L.; Badel, N.; Allebe, C.; Nicolay, S.; Despeisse, M.; Paviet-Salomon, B.; et al. Aluminium-Doped Zinc Oxide Rear Reflectors for High-Efficiency Silicon Heterojunction Solar Cells. IEEE J. Photovolt. 2019, 9, 1217. [CrossRef]

6. Wu, Z.P.; Duan, W.Y.; Lambertz, A.; Qiu, D.P.; Pomaska, M.; Yao, Z.R.; Rau, U.; Zhang, L.P.; Liu, Z.X.; Ding, K.N. Low-resistivity p-type a-Si:H/AZO hole contact in high-efficiency silicon heterojunction solar cells. Appl. Surf. Sci. 2021, 542, 148749. [CrossRef]

7. Geissbühler, J.; De Wolf, S.; Faes, A.; Badel, N.; Jeangros, Q.; Tomasi, A.; Barraud, L.; Descoeudres, A.; Despeisse, M.; Ballif, C. Silicon heterojunction solar cells with copper-plated grid electrodes: Status and comparison with silver thick-film techniques. IEEE J. Photovolt. 2014, 4, 1055. [CrossRef]

8. Yu, J.; Bian, J.; Duan, W.; Liu, Y.; Shi, J.; Meng, F.; Liu, Z. Tungsten doped indium oxide film: Ready for bifacial copper metallization of silicon heterojunction solar cell. Sol. Energy Mater Sol. Cells 2016, 144, 359. [CrossRef]

9. Khanna, A.; Ritzau, K.-U.; Kamp, M.; Filipovic, A.; Schmiga, C.; Glatthaar, M.; Aberle, A.G.; Mueller, T. Screen-printed masking of transparent conductive oxide layers for copper plating of silicon heterojunction cells. Appl. Surf. Sci. 2015, 349, 880. [CrossRef]

10. Li, Z.T.; Hsiao, P.-C.; Zhang, W.; Chen, R.; Yao, Y.; Papet, P.; Lennon, A. Patterning for plated heterojunction cells. Energy Procedia 2015, 67, 76. [CrossRef]

11. Dabirian, A.; Lachowicz, A.; Schüttauf, J.-W.; Paviet-Salomon, B.; Morales-Masis, M.; Hessler-Wyser, A.; Despeisse, M.; Ballif, C. Metallization of Si heterojunction solar cells by nanosecond laser ablation and Ni-Cu plating. Sol. Energy Mater. Sol. Cells 2017, 159, 243. [CrossRef]

12. Meza, D.; Cruz, A.; Morales-Vilches, A.B.; Korte, L.; Stannowski, B. Aluminum-Doped Zinc Oxide as Front Electrode for Rear Emitter Silicon Heterojunction Solar Cells with High Efficiency. Appl. Sci. 2019, 9, 862. [CrossRef]

13. Kang, J.; You, J.S.; Kang, C.S.; Pak, J.J.; Kim, D.W. Investigation of Cu metallization for Si solar cells. Solar Energy Mater. Sol. Cells 2002, 74, 91-96. [CrossRef]

14. Lee, S.H.; Lee, D.W.; Kim, H.J.; Lee, A.R.; Lee, S.H.; Lim, K.J.; Shin, W.S. Study of Cu-X alloy seed layer on ITO for copper-plated silicon heterojunction solar cells. Mater. Sci. Semicon. Proc. 2018, 87, 19. [CrossRef] 